\title{
Dinamika populacij osmerozobega smrekovega lubadarja (Ips typo- graphus) v Sloveniji v letu 2014
}

\author{
Maarten de GROOT ${ }^{1 *}$, Marija KOLŠEK ${ }^{2}$
}

\section{Uvod}

Vremensko dogajanje v letu 2014 je imelo velik vpliv na gostoto oziroma velikost populacij smrekovih podlubnikov. Februarski žled je poškodoval več kot polovico slovenskih gozdov. Najbolj so bili poškodovani gozdovi v Gozdnogospodarskih območjih (GGO) Postojna in GGO Ljubljana. Posek in spravilo poškodovanih smrek v žledolomu je potekalo v okviru razpoložljive delovne sile za delo $\mathrm{v}$ gozdovih. Istočasno $\mathrm{s}$ sanacijo žledoloma je potekala tudi sanacijska sečnja poškodovanih dreves v vetrolomu novembra 2013 (zlasti v GGO Kranj). Poleg tega so tekom leta neurja z močnim vetrom lokalno povzročala posamične poškodbe drevja na celotnem območju Slovenije. V kolikor poškodovane smreke niso bile pravočasno spravljene iz gozda, se je na njih razvila in izletela nova generacija smrekovih podlubnikov (Ips typographus in Pityogenes chalcographus). Kjer je iz poškodovanih smrek izletela tudi druga generacija, lahko v naslednjem letu pričakujemo izredno velike poškodbe gozdov zaradi smrekovih podlubnikov.

$\mathrm{Na}$ podlagi analize podatkov ulova podlubnikov $\mathrm{v}$ feromonske kontrolne pasti $\mathrm{v}$ tem prispevku prikazujemo trend razvoja populacij osmerozobega smrekovega lubadarja (I. typographus) po GGO v letu 2014. Nekaj analiz in napovedi razvoja populacij smrekovih podlubnikov na podlagi ulova v pasti v letu 2014 je bilo že narejenih (De Groot, 2014; Ogris, 2014), vendar so bile te osredotočene na prenamnožitev populacij $I$. typographus v spomladanskem obdobju. Šteje se, da je populacija prenamnožena, ko kumulativni ulov od začetka rojenja do 15. junija preseže 9000 osebkov na kontrolno past. $\mathrm{V}$ tem prispevku prikazujemo rezultate ulova $\mathrm{v}$ feromonske pasti v celotnem obdobju lovljenja v letu 2014 za vse GGO in analiziramo dinamiko populacij.

\section{Materiali in metode}

V letu 2014 je Zavod za gozdove Slovenije (ZGS) v računalniško aplikacijo "Varstvo gozdov" (Ogris, 2012) redno vnašal podatke o ulovu v 1748 feromonskih kontrolnih pasti tipa Theyson. Uporabljeni so bili naslednji feromoni za I. typographus: IT-Ecolure tubus maxi, Pheroprax ${ }^{\circledR}$ and Pheroprax ${ }^{\circledR}$ top. Število pasti po posameznem GGO je bilo od 6 v GGO Kranj do 367 v GGO Slovenj Gradec (preglednica 1). Večina pasti je bila redno vzdrževana oz. praznjena. Najmanjše število praznjenj je bilo eno praznjenje na past, največje 21 praznjenj. Povprečno je bilo 6 praznjenj na past $\mathrm{v}$ celotnem letu.

V analizo trenda populacij I. typographus so bili zajeti podatki o ulovu v celotnem letu 2014 v 1747 pasteh. Po GGO smo izrisali grafikone, v katerem prikazujemo kumulativne ulove osebkov na posamezno past na datum praznjenja v letu 2014. Ker so bile na terenu postavljene pasti različnih tipov (enojne, dvojne ali trojne - zvezdaste), je bilo število ulovljenih hroščkov predhodno deljeno $\mathrm{s}$ številom režastih škatel tipa Theyson na eni pasti. Regresijske oz. trendne črte $\mathrm{V}$ grafikonih so bile izračunane $\mathrm{z}$ uporabo nelineranega mešanega modela (GAMM). Pri izračunu je bila past uporabljena kot naključni dejavnik, ker nas je zanimalo spreminjanje kumulativnega ulova $\mathrm{v}$ posamezni pasti. Po GGO podajamo število pasti, v katerih je bil ulov do 15. junija večji od 9000 osebkov (Pravilnik o varstvu ... , 2009).

\section{Rezultati in razprava}

V GGO Bled je bil povprečen ulov relativno majhen z maksimumom nekaj nad 3800 osebkov (slika 1a, preglednica 1). Največje število ujetih osebkov v posamezni pasti je bilo nekaj nad 2000. Le v $1 \%$ pasti (1 past) je bil ulov do 15. junija večji od 9000 osebkov.

Tudi v GGO Brežice je bil povprečen ulov relativno majhen (slika 1b). Kljub temu je bil v GGO Brežice zabeležen največji ulov na eno past od vseh analiziranih pasti, to je 76000 osebkov (preglednica 1). V $14 \%$ pasti (20 pasti) je bil ulov do 15. junija večji od 9000 osebkov.

Povprečen ulov v GGO Celje je presegel prag prenamnožitve 9000 osebkov (slika 1c). Kar v $15 \%$ pasti je bil ulov do 15. junija večji od 9000 osebkov. Največji ulov v posamezno past je bil 47000 osebkov. Vzrok za namnožitev podlubnikov so sestoji s smreko na majhnih nadmorskih višinah, na katerih je smreka bolj občutljiva na stresne dejavnike.

V GGO Kočevje je povprečen ulov relativno majhen (slika 1d). Rast populacije se je začela dokaj pozno zaradi višjih nadmorskih višin. Največji ulov v posamezno past je bil skoraj 55000 osebkov, kar je tretji največji ulov od vseh v analizo zajetih pasti. Samo v 2 $\%$ pasti (5 pasti) je bil ulov do 15 . junija večji od 9000 osebkov.

GGO Kranj je v računalniško aplikacijo "Varstvo gozdov" vnesel podatke o ulovu le nekaj pasti (slika 1e, preglednica 1). $\mathrm{V}$ nobeni od teh pasti ulov ni bil večji od 9000 osebkov (največji ulov na past je bil 8000 osebkov). Kljub temu iz gostote populacije podlubnikov v okoliških GGO (Bled, Ljubljana in Tolmin) lahko sklepamo, da so tudi v GGO Kranj smrekovi podlubniki namnoženi.

V GGO Ljubljana je povprečen ulov relativno majhen (slika 1f). V posamezno past se je ujelo največ 22220 osebkov. V $8 \%$ pasti (10 pasti) je bil ulov do 15. junija večji od 9000 osebkov. Trendna črta je primerljiva s trendnimi črtami v drugih GGO.

Povprečen ulov v GGO Maribor ni presegel prag prenamnožitve 9000 osebkov (slika $1 \mathrm{~g}$ ). V eno past se 
je ujelo največ 48000 osebkov. V $4 \%$ pasti (4 pasti) je bil ulov do 15. junija večji od 9000 osebkov.

Povprečen ulov v GGO Murska Sobota je bil največji med vsemi GGO in je presegel prag prenamnožitve 9000 osebkov (slika 1h). Skoraj v $36 \%$ pasti je bil ulov do 15. junija večji od 9000 osebkov (preglednica 1). Največji ulov v posamezno past je bil 70000 osebkov. Vzrok v velikem ulovu oz. namnožitvi podlubnikov v GGO Murska Sobota so sestoji s smreko na smreki neustreznih nizkih nadmorskih višinah.

V GGO Nazarje je povprečen ulov relativno majhen (maksimum 2713 osebkov) (slika 1i). Samo v $1 \%$ pasti (4 pasti) je bil končni ulov večji od 9000 osebkov. Največji ulov v posamezno past je bil 27200 osebkov.

Povprečen ulov v GGO Novo mesto je daleč pod pragom namnožitve (slika 1j). Vendar je bil v kar $14 \%$ pasteh (8 pasti) končni ulov večji od 9000 osebkov.

Nekaj posebnega je povprečen ulov v GGO Postojna s povečanjem ob koncu maja (slika 1k), ki pa ne odraža dinamike gostote populacije I. typographus. To je posledica zakasnele postavitve pasti na tem območju, ki je bilo najbolj prizadeto $\mathrm{v}$ februarskem žledolomu. V nobeni od pasti ulov do 15 . junija ni bil večji od 9000 osebkov.

Iz GGO Sežana je bilo v analizo zajetih sedem pasti, ki so bile vzdrževane največ do 2. julija. Zato je trendna črta strma, vendar ulov $\mathrm{v}$ nobeni od pasti ni presegel praga prenamnožitve (9000 osebkov) pred 15 . junijem (slika 11). Največji ulov v posamezno past je bil 11560 osebkov.

V GGO Slovenj Gradec je bil povprečen ulov pod pragom prenamnožitve (slika $1 \mathrm{~m}$ ). V $0,3 \%$ pasti (1 past) je bil ulov do 15. junija večji od 9000 osebkov. Največji ulov v posamezno past je bil 22400 osebkov.

V GGO Tolmin je bil povprečen ulov majhen (slika 1n). Samo v $2 \%$ pasti (1 past) je bil ulov do 15 . junija večji od 9000 osebkov. Največji ulov v posamezno past je bil 26400 osebkov.

Ker je bil popis ulova (praznjenje pasti) večine analiziranih pasti izveden daleč pred oziroma po razvoju prve generacije (15. junij), to otežuje določitev številčnosti populacije na ta dan. Predvidevamo, da je ulov v večjem številu pasti presegel 9000 osebkov do 15. junija, kot smo ga ugotovili z analizo podatkov ulova. Zato predlagamo, da se pasti $\mathrm{v}$ naslednjih letih nujno čistijo enkrat na 10 dni pred 15 . junijem. S podatki o teh ulovih bo mogoče bolj natančno določiti pasti oziroma območja, kjer je populacija I. typographus prenamnožena.

Na splošno so bili povprečni ulovi $\mathrm{v}$ feromonske kontrolne pasti za I. typographus v letu 2014 majhni, kar je bilo glede na posledice februarskega žledoloma tudi pričakovano. Zaradi velikega števila svežih poškodovanih smrek feromonske vabe niso privabile toliko osebkov, kot bi jih, če žledoloma ne bi bilo. Kljub temu je analiza podatkov o ulovu pokazala povečanje številčnosti populacije $I$. typographus. Pravi vpliv žledoloma na številčnost populacije podlubnikov se bo pokazal šele pri popisu poznopoletnih žarišč podlubnikov, ki jih je povzročila druga generacija podlubnikov. Predvidevamo, da bo v letu 2015 na območju žledoloma prišlo do prenamnožitve podlubnikov.

\section{Zahvala}

Zahvaljujemo se sodelavcem Zavoda za gozdove Slovenije za spremljanje in evidentiranje podatkov o ulovu v feromonske pasti v aplikacijo VG.

\section{Viri}

De Groot, M. 2014. Trendi in napovedi gostote populacij smrekovih podlubnikov po žledolomu 2014 v Sloveniji: stanje pomlad 2014. Napovedi o zdravju gozdov, 2014.

Ogris, N. 2012. Prognostične osnove za varstvo gozdov Slovenije. Ljubljana, Silva Slovenica: 104 str.

Ogris, N. 2014. Spremljanje ulova osmerozobega smrekovega lubadarja v kontrolnih pasteh v Sloveniji v 2014: ocena prenamnožitve populacije na ravni posamezne pasti. Napovedi o zdravju gozdov, 2014.

Pravilnik o varstvu gozdov. Uradni list RS št. 114-5220/2009

${ }^{1}$ Gozdarski Inštitut Slovenije, Večna pot 2, 1000 Ljubljana ${ }^{2}$ Zavod za gozdove Slovenije, Večna pot 2, 1000 Ljubljana *maarten.degroot@gozdis.si 


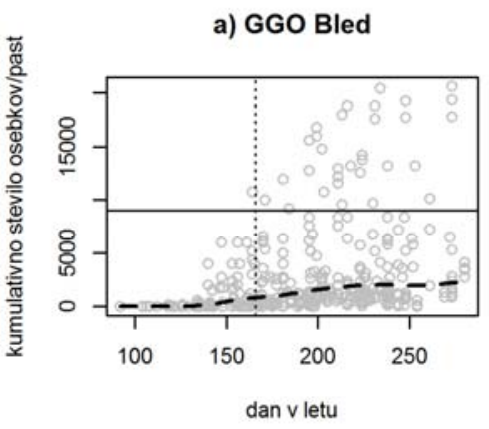

d) GGO Kocevje
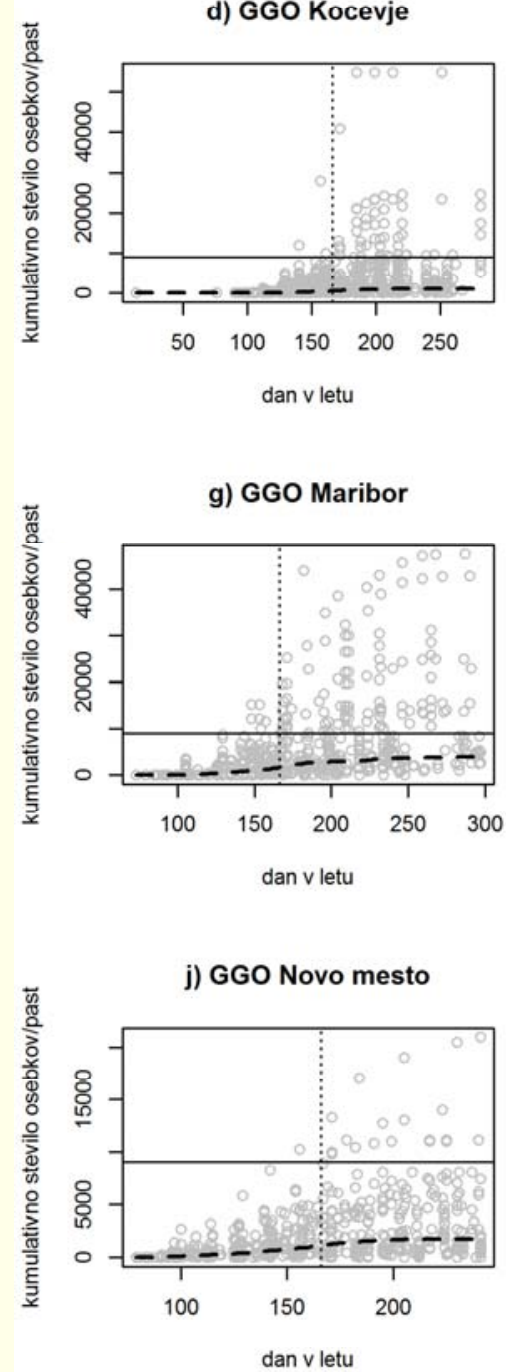

m) GGO Slovenj Gradec

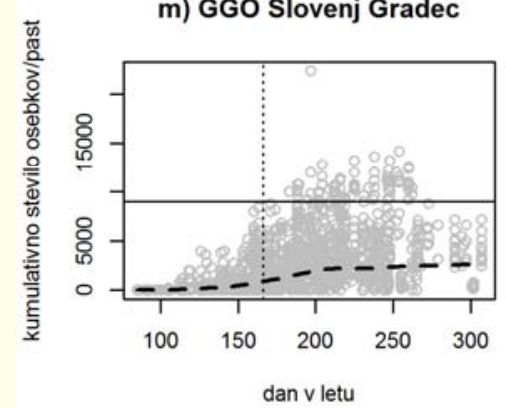

b) GGO Brežice

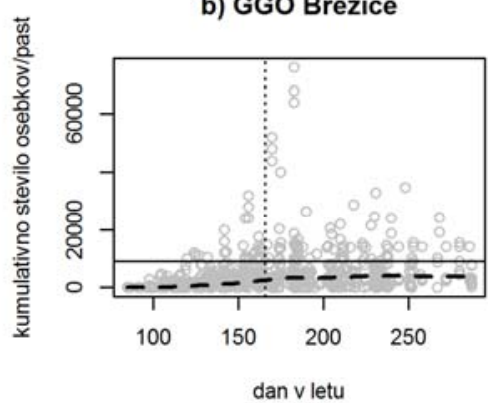

e) GGO Kranj

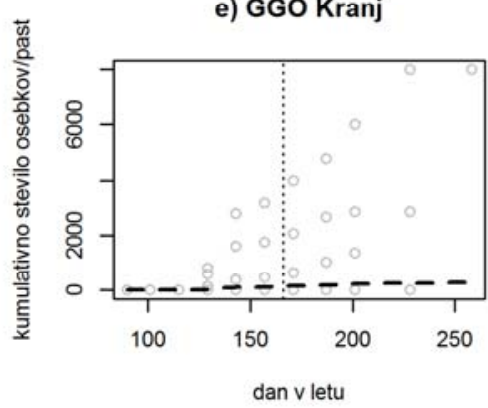

h) GGO Murska Sobota

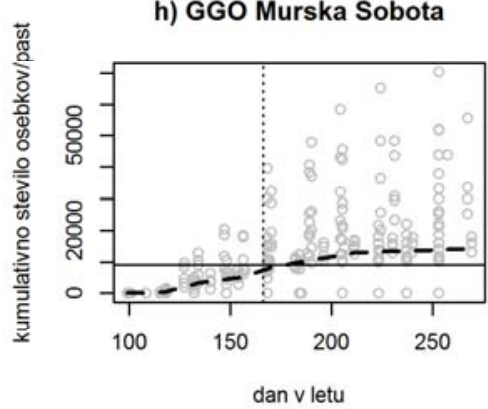

k) GGO Postojna

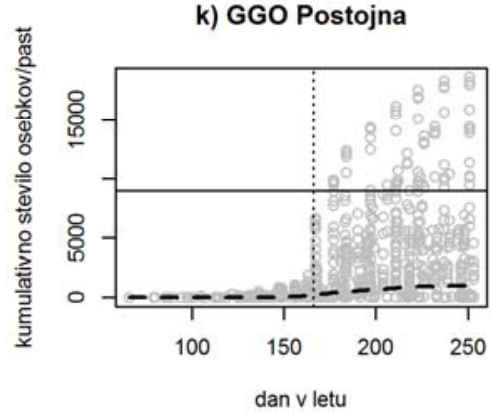

n) GGO Tolmin

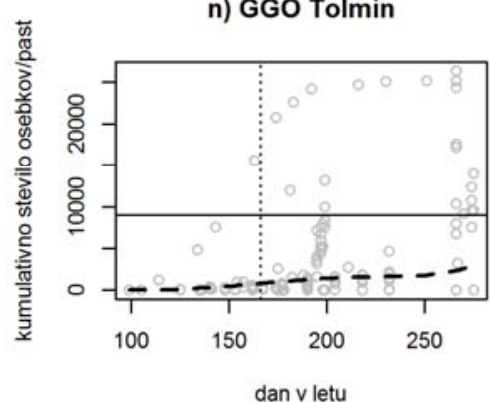

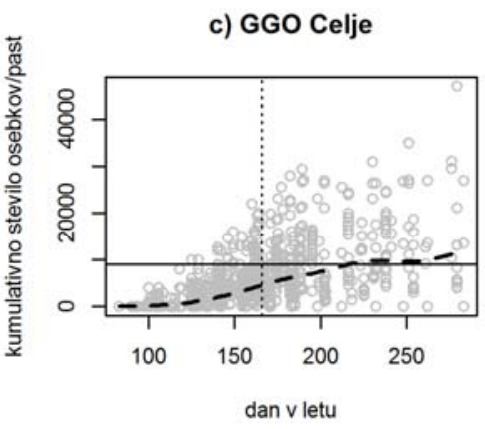
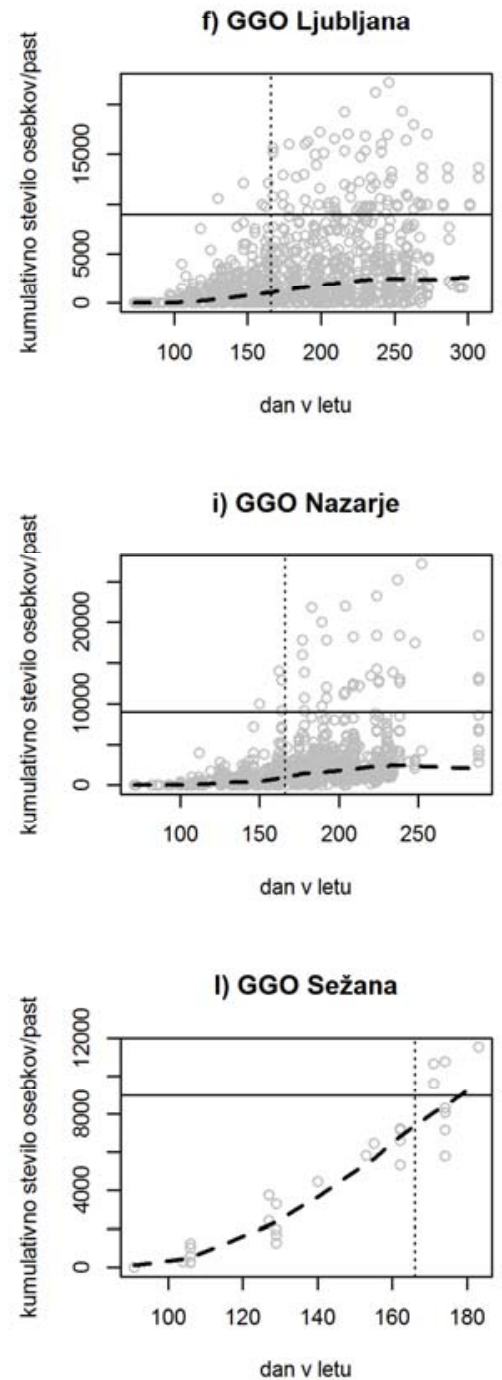

Slika 1: Kumulativno naraščanje števila osebkov Ips typographus v sezoni 2014 v Sloveniji po GGO. Datum je prikazan kot dan v letu. Črna horizontalna črta označuje prag 9000 osebkov (Pravilnik o varstvu ..., 2009), navpična črta označuje 15. junij 2014. 
Preglednica 1: Statistika števila osebkov Ips typographus v kontrolnih pasteh v 2014 do 24. 10. 2014

\begin{tabular}{|c|c|c|c|c|c|c|}
\hline GGO & $\begin{array}{r}\text { Število } \\
\text { pasti }\end{array}$ & $\begin{array}{r}\text { Povprečni zadnji } \\
\text { datum } \\
\text { praznjenja pasti }\end{array}$ & $\begin{array}{r}\text { Zadnji datum } \\
\text { praznjenja } \\
\text { pasti }\end{array}$ & $\begin{array}{r}\text { Povprečno } \\
\text { kumulativno število } \\
\text { osebkov na past / } \\
\text { GGO }\end{array}$ & $\begin{array}{r}\text { Največje } \\
\text { kumulativno } \\
\text { število osebkov na } \\
\text { past / GGO }\end{array}$ & $\begin{array}{r}\text { Število pasti z } \\
\text { več kot } 9000 \\
\text { osebki pred } 15 . \\
\text { junijem }\end{array}$ \\
\hline Bled & 79 & 25.8 .2014 & 7.10 .2014 & 3.832 & 20.600 & 1 \\
\hline Brežice & 139 & 4.8 .2014 & 14.10 .2014 & 7.547 & 76.000 & 20 \\
\hline Celje & 174 & 17.7 .2014 & 10.10 .2014 & 9.576 & 47.000 & 26 \\
\hline Kočevje & 208 & 20.7.2014 & 8.10 .2014 & 2.448 & 54.872 & 5 \\
\hline Kranj & 6 & 31.7 .2014 & 15.9 .2014 & 2.173 & 8.000 & 0 \\
\hline Ljubljana & 131 & 21.8 .2014 & 3.11 .2014 & 4.275 & 22.220 & 10 \\
\hline Maribor & 104 & 14.8 .2014 & 24.10 .2014 & 6.750 & 47.680 & 4 \\
\hline $\begin{array}{l}\text { Murska } \\
\text { Sobota }\end{array}$ & 25 & 15.9.2014 & 26.9.2014 & 23.824 & 70.400 & 9 \\
\hline Nazarje & 302 & 25.7 .2014 & 15.10 .2014 & 2.713 & 27.200 & 4 \\
\hline Novo mesto & 57 & 19.8 .2014 & 29.8 .2014 & 3.523 & 21.000 & 7 \\
\hline Postojna & 108 & 24.8 .2014 & 10.9 .2014 & 3.225 & 18.700 & 0 \\
\hline Sežana & 7 & 14.6 .2014 & 2.7 .2014 & 7.437 & 11.560 & 0 \\
\hline $\begin{array}{l}\text { Slovenj } \\
\text { Gradec }\end{array}$ & 367 & 15.8 .2014 & 3.11 .2014 & 3.470 & 22.400 & 1 \\
\hline Tolmin & 41 & 27.8 .2014 & 2.10 .2014 & 6.496 & 26.400 & 1 \\
\hline
\end{tabular}

